\title{
Public Investment and EU Funds in a Small Open Economy Integrated in the Euro Area
}

\author{
Stanislav TVRZ, Martin ŽELEZNÍK \\ National Bank of Slovakia, Bratislava, Slovak Republic \\ \{stanislav.tvrz, martin.zeleznik\}@nbs.sk
}

\begin{abstract}
Small open economies within the European Union can be extensively influenced by the utilization of the structural and investment EU funds. Even more so if they are eligible to draw from the Cohesion Fund targeted at the less developed EU countries. In many of these countries, we observe an EU-funds cycle that causes spikes in total investment as the programming period draws near to its end, and a decline after the new programming period begins. As the share of EU-funded public investment and the public investment financed from domestic sources varies highly over time, we decided to explore the differences in the transmission of these two types of public investment shocks into the real economy. We use a version of the EAGLE model calibrated for the Slovak economy integrated in the euro area and extended with EU funds mechanisms. We find that if the part of the total investment that is funded from domestic sources comes from an increase in taxes, the EU-funded investment delivers larger improvement in real GDP. The difference is especially striking for investment funded by an increase of social security contributions paid by firms. Debt-financed public investment delivers virtually the same results irrespective of whether it is co-financed from EU funds or not.
\end{abstract}

Keywords: DSGE Model, EU Funds, Public Investment, Taxes.

\section{Introduction}

The European Structural and Investment Funds (ESIF) provide fiscal transfers from the richer EU Member States to the countries and regions that are lagging behind in terms of per capita GDP. According to [7] the net position of Slovakia over period 2007-2015 was $1.8 \%$ of GDP. Funds for regional and cohesion policy allocated for period 20142020 amount to $€ 351.8$ bn, $€ 15.3$ bn of which are allocated for the Slovak Republic. This represents an average of 2.830 euro per person from the EU budget over the period 2014-2020. National contribution is supposed to be 4.7 billion. So far only $5.3 \%$ of the total amount was spent [5].

Small open economies within the European Union can be extensively influenced by the utilization of the EU funds. Even more so if they are eligible to draw from the Cohesion Fund targeted at the less developed EU countries. In many of these countries, we observe an EU-funds cycle that causes spikes in total investment as the programming period draws to its end, and a decline after the new programming period 
begins. As the share of EU-funded public investment and the public investment financed from domestic sources varies highly over time, we decided to explore the differences in the transmission of these two types of public investment shocks into the real economy. The aim of this paper is to evaluate the potential impact of Structural and Cohesion Fund programmes for the small open economy that is part of the euro area and which is a net recipient of the funds.

For simulation of scenarios related to cohesion policy there have been at least two models used in the literature - HERMIN [1] and QUEST.

In order to fulfill our goal, a micro-founded dynamic general equilibrium model is used. We use the multi-country model of the euro area - EAGLE], its fiscal extension that incorporates productive government spending and investment, and furthermore, we introduce another extension that allows us to explore the effects of changes in the drawing of the EU funds.

The rest of the paper is organized as follows: Section 2 describes the main features of the EAGLE model and its extensions; Section 3 summarizes the calibration of the model; Section 4 contains the main contribution of this paper - the impulse response analysis; and the final section concludes.

\section{The model}

\subsection{The EAGLE and its extension}

In this section the brief overview of the EAGLE model is presented. For more details, see the original paper Calibration of this benchmark version for Slovakia was created and used for policy simulations in [9].

The model is structured into four symmetric regions of the world economy. Three regions form a monetary union with common monetary policy and fixed exchange rate. There are two types of households - Ricardians (I-type) and non-Ricardians (J-type), which differ in having (I) or not having (J) an access to the financial markets. Households supply differentiated labor services to intermediate firms, acting as wage setters, which gives us an opportunity to introduce nominal rigidities in the labor market. Wage rigidities are modelled using the Calvo [2] framework.

Intermediate good firms operate in monopolistically competitive markets and use a Cobb-Douglas production function to produce tradeable and non-tradable goods. Nontradable products can be consumed only domestically while tradable products can be also exported. Prices of the differentiated tradeable and non-tradeable goods varieties are set again according to the Calvo-type mechanism with indexation.

Final goods sector contains perfectly competitive firms who aggregate different domestic non-tradable, tradable and imported goods into the final product. Final production is divided in following sectors - consumption, investment and export.

Monetary authority follows a Taylor rule in setting interest rates according to the deviations of inflation and output growth from their target levels. In the monetary union, the response of monetary policy is due to deviations from policy targets of the union as a whole, rather than in individual member countries. 
Fiscal authority collects tax revenues, both proportional and lump-sum, earns seigniorage on money holdings and issues bonds to finance its debt. In the original framework, these funds are used to purchase domestic non-tradable goods and to makes transfers to households. Work by further extends the model in a way that government spending can contain an imported component as is usually seen in small open economies (SOEs) simply because many of the goods purchased by the government are not produced domestically. Further, they introduce complementarity between public and private consumption in line with [4] and [8], and also a productive government investment that can increase the productivity of private capital. Public capital appears as an additional production factor in the Cobb-Douglas production function of intermediate good producing firms.

\subsection{Modelling of public investment and EU funds}

In order to simulate shocks in public investment funded either wholly from domestic sources or with co-financing from EU funds, we introduce another extension of the model inspired by the expenditure side of the budget constraint of the government we added the part of EU funds that is sent as a payment to the European union, $\mathrm{EU}_{\mathrm{t}}^{\mathrm{OUT}}$, and on the revenue side, we added a variable $E U_{t}^{I N}$ that tells us the amount of money that comes to the country from the EU. Payment sent to the EU is proportional to the size of the economy, which leads to the same amount paid in per capita terms across the EU:

$$
E U_{t}^{O U T}=\frac{{ }^{C \mathrm{CO}_{1}} \mathrm{EU}_{t}^{I N, \mathrm{CO}_{1}}+\mathrm{S}^{\mathrm{CO}_{2}} \mathrm{EU}_{t}^{I N, \mathrm{CO}_{2}}+\mathrm{CO}_{3} \mathrm{EU}_{t}^{I N, \mathrm{CO}_{3}}}{s^{\mathrm{CO}_{1}+s^{C O}}{ }_{2}+\mathrm{CO}_{3}},
$$

where $S^{\mathrm{CO}_{1}}$ is weight of a country in the union.

We define the total government investment in the following manner:

$$
G_{I, t}=\frac{E U_{t}^{I N}}{P_{G_{I}, t}}+G_{I_{C}, t}+G_{I_{A}, t}
$$

where $G_{I_{C}, t}$ is the part of government investment that is generated by the incoming EU funds due to compulsory co-financing by the home country:

$$
G_{I_{C}, t}=\chi^{E U} \frac{E U_{t}^{I N}}{P_{G_{I}, t}}
$$

where $\chi^{E U}$ is the co-financing parameter. The last remaining part of the total public investment is the autonomous government investment $\mathrm{G}_{\mathrm{I}_{\mathrm{A}}, \mathrm{t}}$ that is decided and paid from domestic sources independently from the EU funds mechanisms.

Both, the government investment and the drawing of EU funds, are driven by exogenous processes in their respective shares over nominal GDP:

$$
A G I Y_{t}=\frac{G_{I_{A}, t}}{P_{Y, t} Y_{t}},
$$

and 


$$
E U Y_{t}=\frac{E U_{t}^{I N}}{P_{Y, t} Y_{t}} .
$$

Autonomous government investment shock then develops according to:

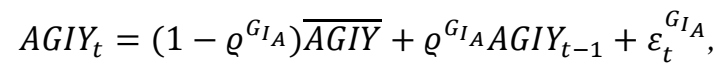

and the EU funds shock is defined as:

$$
E U Y_{t}=\left(1-\varrho^{E U}\right) \overline{E U Y}+\varrho^{E U} E U Y_{t-1}+\varepsilon_{t}^{E U} .
$$

\section{Calibration}

Taking the calibration of the model for the Slovak economy used by [9] as a starting point, we made some necessary updates and adjustments, especially in the fiscal sector. Namely, we set the import shares for the public consumption and investment goods as can be seen in Table 1. We also increased the calibration of nominal rigidities in the domestic tradable and non-tradable sectors, which can be seen in Table 2. Setting of the technology and preference parameters concerning the public consumption and investment goods is presented in Table 3. Extension of the model with EU funds mechanisms lead to a calibration of the $\chi^{\mathrm{EU}}$ co-financing parameter to a value of 0.25 , which results in a ratio of EU funds and domestic funds in EU-funded public investment projects of 4:1. Persistence and volatility parameters of newly defined shocks were calibrated to 0.9 and 0.01 respectively. Tables with the model calibration are included in the Appendix and contain a comparison to the original calibration of [6] and used for Slovenia and Ireland.

\section{$4 \quad$ Impulse Response Analysis}

In this section, results of the model simulations are shown. First, we treat the autonomous government investment shock and EU funds shock separately and compare the different ways of financing the domestic part of the expense. First possibility is the debt-financing by bond issuance without debt repayment on the simulation horizon. Another possibility is to raise taxes. We chose three alternatives - lump-sum tax, VAT tax and an increase in social security contributions (SSC) paid by firms. Taxes are then set in such a way that leads to a stable public debt-to-GDP ratio. Next, we compare the effects of autonomous public investment shock and EU funds shock to each other.

\subsection{Autonomous government investment shock}

Effects of the autonomous public investment increase of 1 percent of ex-ante GDP are depicted in Fig. 2 in the Appendix. First consequence of the shock is roughly 25-percent increase of public investment and an increase of imports across all types of financing. 
On impact, output and hours worked increase because the economy has to produce more intermediate goods to supply the domestically produced part of the public investment.

Private consumption declines across the three types of financing that use the tax increases and rises in the case of financing the government investment through public debt increase without the obligation of immediate repayment. Therefore, the agents in the economy do not have to increase savings and postpone the consumption.

One of the key roles of productive public capital is that the rise of government investment reduces the marginal costs in the medium run and improves the competitiveness of the domestic economy. This leads after the initial demand driven increase of domestic inflation to its reduction and to depreciation of the real effective exchange rate, which stimulates production in the domestic tradable sector and draws in private investment. Alternative types of financing differ only in timing. The main dissimilarity is in financing through social security contributions paid by firms. Since the raise of the SSC paid by firms increases the marginal costs of firms more and for longer period of time, the positive effects do not appear sooner than almost after 5 years after the initial shock. The higher marginal costs translate directly into higher domestic inflation.

The magnitude of the impact on imports relies on the import content of the government investment goods. If it is high, increase of imports leads to a deterioration of the trade balance, but after government capital accumulation takes effect, exports increase too and the trade balance becomes positive.

These results are in line with the intuition that government expenditure aimed at the improvement of infrastructure can reduce private sector's costs and have positive impact on the economy.

Fig. 2 contains also the tax rates setting needed for immediate repayment of the public debt. VAT tax and SSC are expressed as deviation from steady state in percentage points. It means for example that VAT tax has to increase from 20 percent as it is now in Slovakia to roughly 21.75 percentage points to pay for the amount of government investment.

In our exercise, the most beneficial scenario seems to be the one where government investments are debt-financed while the worst results are obtained by increasing the SSC paid by firms.

\subsection{EU funds shock}

As the previous EU funds programming period of 2007-2014 was prolonged by 1 year in order to allow for completion delayed projects, larger than expected amount of allocated funds was drawn by the very end of 2015, which brought about positive surprises in investment. Since then, we observe the opposite development as the new projects eligible for co-financing from EU funds are finalized and approved only slowly and there is a negative surprise in investment every forecasting round.

The EU funds shock leads to the same (1 percent share of nominal GDP) increase in the total public investment as the autonomous public investment shock. The important difference is that under our calibration $80 \%$ of the whole volume is financed via the 
EU funds and only $20 \%$ is co-financed from the domestic sources. The domestic cofinancing is again paid-off by the same four types of debt or tax financing. The results are depicted in Fig. 3 in the Appendix.

The transmission channels are the same as in the previous scenario, but significant differences appear in the magnitudes of reactions in individual variables.

First interesting result is that the public debt in debt-financed scenario decreases slightly during the first year. The reason behind this is that this variable is defined as public debt to GDP ratio and GDP increase on impact is higher than the increase of domestic public debt, which is used only for the co-financing of the whole project. Imports increase once again according to the import content of government investment and according to the import content in other sectors of domestic economy. Hours worked increase as the firms hire more labor to be able to supply the domestically produced part of the investment. Marginal costs rise on impact, but decline in the medium run. The same holds for CPI inflation, which influences the competitiveness of the economy and draws in the private investment and bolsters exports in medium run. Taxes are set in order to balance the public debt in the three tax scenarios, so they decrease initially because the public debt would decline on impact. As public debt rises in medium run, tax hikes are needed.

Comparison of the alternative ways of domestic co-funding of the EU funds projects shows that the debt-financing is the best option from the point of view of GDP while the increase of SSC paid by firms would be the least preferred alternative.

\subsection{Comparison: Government investment shock vs. EU funds shock}

We now turn to the comparison of the autonomous government investment shock and the EU funds shock from the point of view of real GDP under the different scenarios of funding the domestic part of the investment. The results are presented in Fig. 1.

Debt-financing. We work with a model of the monetary union that assumes the existence of common European bond guaranteed by all the member states. Therefore it is irrelevant which country issues the new debt through Eurobonds - be it the home country in case of autonomous government investment shock or the rest of the EU in case of EU funds. In both cases, the newly issued Eurobonds are bought by agents from across the EU on the common bond market. Therefore, there is little difference between the two shocks under this type of financing.

Lump-sum tax. The main difference between the two shocks in terms of GDP is the larger initial increase in case of EU funds shock. This is given by the fact that the shock is not accompanied by such a large tax hike as in the case of public investment funded wholly from domestic sources. Higher aggregate demand in the case of EU funds shock leads to higher consumption, hours worked and consequently also marginal costs of firms and higher inflation. Because of that, the real effective exchange rate appreciates and domestic exporters become increasingly less competitive. As a result, the deviation of the GDP after the EU funds shock approaches the autonomous government investment alternative in the medium run. 
VAT tax. The main differences in the transmission of the two public investment shocks are the same as in the case of Lump-sum tax. However, the distortionary effects of the VAT tax on the decision making of households cause smaller GDP increase after the autonomous public investment shock and larger gap between the two shocks overall.
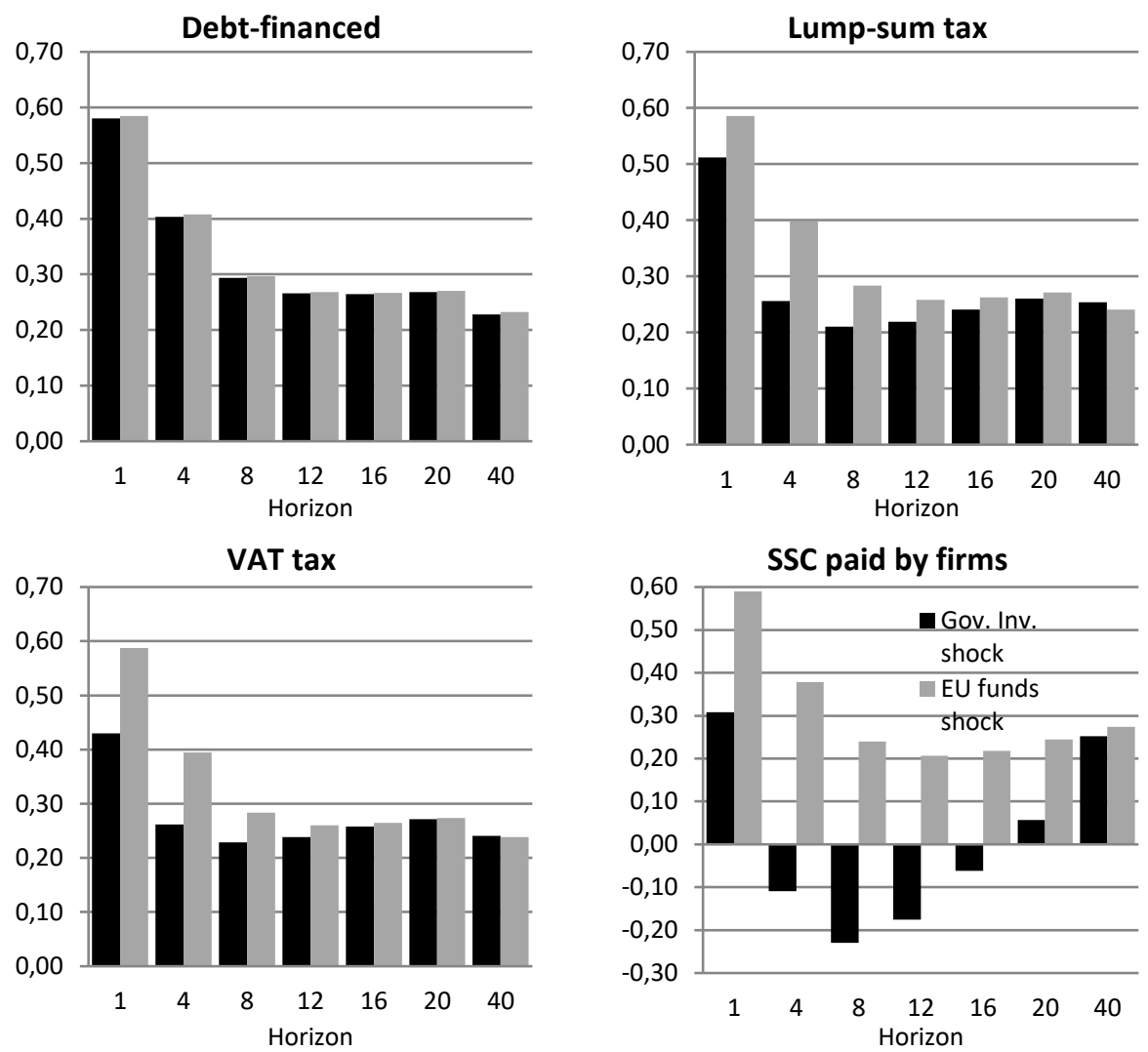

Fig. 1. Response of GDP by shock and type of financing (in \% of steady state).

SSC paid by firms. The transmission mechanism is now different. In this scenario the higher rise in SSC paid by firms leads to higher marginal costs for the firms when public investment is financed wholly from domestic sources. This translates directly into higher domestic inflation and lower consumption. Higher inflation also implies higher appreciation of the real exchange rate, which depresses the private investment and exports for almost 4 years after the initial shock. The EU funds shock generates substantial positive effects in the GDP over the whole simulation horizon. Should the investment be funded by SSC paid by firms, the EU funds are thus much better choice for government investment. 


\section{Conclusion}

Using EAGLE - a multi-country DSGE model with monetary union setup and extended fiscal sector - we have analyzed and compared the transmission of autonomous government investment shock and EU funds shock into the home economy. We have arrived at several interesting findings relevant for a small euro area economy, such as the Slovak Republic. Due to the assumption of common EU wide bonds market, the debt-financed public investment would have the same impact on the home economy irrelevant of the co-financing from the EU funds. On the other hand, the way of financing the domestic part of the whole public investment project, can have important macroeconomic consequences. Since, the tax hikes needed for domestic (co-)financing of the public investment depress the domestic aggregate demand, the impacts of EUfunded investment on GDP are generally stronger. Unlike the lump-sum tax and VAT tax hikes, the increase of social security paid by firms is inflationary in itself, which translates not only into loss of aggregate demand but also immediate loss of competitiveness in the international trade, making this way of financing the least desirable from the point of view of GDP.

Disclaimer. The views expressed in this paper are those of the authors and do not necessarily reflect the official views of the National Bank of Slovakia.

\section{References}

1. Bradley, E., Untiedt, G., Morgenroth, E.: Macro-regional evaluation of the structural funds using the HERMIN modelling framework. Italian Journal of Regional Science, 1(3), 5-28. (2003).

2. Calvo, G. Staggered prices in a utility-maximizing framework. Journal Of Monetary Economics 12(3), 383-398 (1983), http://dx.doi.org/10.1016/0304-3932(83)90060-0.

3. Clancy, D., Jacquinot, P., Lozej, M.: Government expenditure composition and fiscal policy spillovers in small open economies within a monetary union. Journal Of Macroeconomics 48, 305-326 (2016), http://dx.doi.org/10.1016/j.jmacro.2016.04.003.

4. Coenen, G., Straub, R., Trabandt, M.: Fiscal Policy and the Great Recession in the Euro Area. American Economic Review 102(3), 71-76 (2012), http://dx.doi.org/10.1257/aer.102.3.71.

5. European Structural and Investment Funds, https://cohesiondata.ec.europa.eu/, last accessed 2017/1017.

6. Gomes, S., Jacquinot, P., Pisani, M.: The EAGLE. A model for policy analysis of macroeconomic interdependence in the euro area. Economic Modelling 29(5), 1686-1714 (2012), http://dx.doi.org/10.1016/j.econmod.2012.04.002.

7. Národná Banka Slovenska.: Rozdelenie benefitov spoločného rozpočtu EÚ medzi členské štáty, Analytická štúdia NBS, https://www.nbs.sk/_img/Documents/_komentare/AnalytickeKomentare/2017/AS43_Rozd elenie_benefitov_spolocneho_rozpoctu_EU_medzi_clenske_staty.pdf, last accessed 2017/08/26. 
8. Leeper, E., Walker, T., \& Yang, S.: Government investment and fiscal stimulus. Journal Of $\begin{array}{lll}\text { Monetary } & \text { Economics } & \text { 57(8), } \\ \text { http://dx.doi.org/10.1016/j.jmoneco.2010.09.002. }\end{array}$

9. Senaj, M., Výškrabka, M.: Labor Tax Harmonization in a Multi-Country model. Finance a úvěr-Czech Journal of Economics and Finance 65(3), 192-210 (2015).

10. Varga, J., Veld, Jan in't: A model-based assessment of the macroeconomic impact of EU structural funds on the new Member States, Economic Papers 371 (March 2009), 1-31 (2009).

\section{Appendix}

Table 1. Steady-state national accounts and trade matrix (as \% of nominal GDP).

\begin{tabular}{lrrr}
\hline & SK & IE & SI \\
\hline Great ratios & & & \\
\hline Private consumption & 0.561 & 0.5791 & 0.5692 \\
Private investment & 0.225 & 0.176 & 0.1506 \\
Target public debt (\% of GDP) & 0.6000 & 0.6000 & 0.6000 \\
\hline Trade linkages & & & \\
\hline Imports & 0.9349 & 0.6300 & 0.6981 \\
Consumption goods & 0.2060 & 0.1498 & 0.2203 \\
From REA & 0.0446 & 0.0543 & 0.1758 \\
From DE/US & 0.0251 & 0.0737 & 0.0436 \\
From RW & 0.1364 & 0.0218 & 0.0009 \\
Investment goods & 0.1142 & 0.0972 & 0.1297 \\
From REA & 0.0288 & 0.0343 & 0.1011 \\
From DE/US & 0.0333 & 0.0465 & 0.0252 \\
From RW & 0.0520 & 0.0164 & 0.0034 \\
Imports for export goods & 0.5526 & 0.3530 & 0.3181 \\
From REA & 0.1907 & 0.1130 & 0.2340 \\
From DE/US & 0.0401 & 0.1532 & 0.0693 \\
From RW & 0.3218 & 0.0868 & 0.0148 \\
Government expenditure & & & \\
Public consumption & 0.1900 & 0.1290 & 0.2080 \\
Imports & 0.0456 & 0.0200 & 0.0200 \\
Public investment & 0.0350 & 0.0400 & 0.0400 \\
Imports & 0.0165 & 0.0100 & 0.0100 \\
\hline Country size & & & \\
\hline Size (as \% of world GDP) & 0.0110 & 0.0300 & 0.0200 \\
\hline & & &
\end{tabular}

Table 2. Calibration - Real and Nominal Rigidities.

\begin{tabular}{lrrrrrr}
\hline & SK & IE & SI & REA & DE & RW \\
\hline Real rigidities & & & & & & \\
\hline Investment adjustment $\left(\Gamma_{I}\right)$ & 3 & 6 & 3 & 6 & 4 & 4 \\
Import adjustment $\left(\right.$ cons., $\left.\Gamma_{I M^{c}}\right)$ & 1 & 5 & 1 & 5 & 5 & 5 \\
Import adjustment (inv., $\left.\Gamma_{I M^{I}}\right)$ & 1.5 & 2 & 1.5 & 2 & 2 & 2 \\
Quasi-share of govt cons. $\left(v_{C C E S}\right)$ & 0.25 & 0.25 & 0.25 & 0.25 & 0.20 & 0.20 \\
Complementarity of gov. and priv. cons. $\left(\mu_{C C E S}\right)$ & 0.15 & 0.20 & 0.20 & 0.29 & 0.33 & 0.33
\end{tabular}




\begin{tabular}{lllllll}
\hline Nominal rigidities & & & & & & \\
\hline Wage stickiness $\left(\xi_{I}, \xi_{I}\right)$ & 0.75 & 0.80 & 0.81 & 0.78 & 0.78 & 0.78 \\
Wage indexation $\left(\chi_{I}, \chi_{J}\right)$ & 0.75 & 0.75 & 0.75 & 0.75 & 0.75 & 0.75 \\
Price stickiness (domestic, $\left.\xi_{N}\right)$ & 0.92 & 0.75 & 0.75 & 0.79 & 0.79 & 0.79 \\
Price indexation (domestic, $\left.\chi_{N}\right)$ & 0.70 & 0.50 & 0.50 & 0.70 & 0.70 & 0.70 \\
Price stickiness (imported, $\left.\xi_{X}\right)$ & 0.75 & 0.75 & 0.75 & 0.75 & 0.75 & 0.75 \\
Price indexation (imported, $\left.\chi_{X}\right)$ & 0.70 & 0.50 & 0.50 & 0.70 & 0.70 & 0.70 \\
Price stickiness (services, $\left.\xi_{H}\right)$ & 0.92 & 0.75 & 0.93 & 0.79 & 0.79 & 0.79 \\
Price indexation (services, $\left.\chi_{H}\right)$ & 0.70 & 0.50 & 0.50 & 0.70 & 0.70 & 0.70 \\
\hline
\end{tabular}

Table 3. Calibration - Households and Firms.

\begin{tabular}{|c|c|c|c|}
\hline & SK & IE & SI \\
\hline \multicolumn{4}{|l|}{ Households } \\
\hline Subjective discount factor $(\beta)$ & $1.03^{1 / 4}$ & $1.03^{1 / 4}$ & $1.03^{1 / 4}$ \\
\hline Depreciation rate (private capital, $\delta$ ) & 0.025 & 0.025 & 0.025 \\
\hline Depreciation rate (public capital, $\delta_{G}$ ) & 0.025 & 0.025 & 0.025 \\
\hline Int. elasticity of substitution $\left(\sigma^{-1}\right)$ & 1 & 1 & 1 \\
\hline Share of J-type households $(\omega)$ & 0.5 & 0.25 & 0.25 \\
\hline Habit formation $(\kappa)$ & 0.7 & 0.6 & 0.6 \\
\hline Frisch elasticity of labour (inverse, $\zeta$ ) & 2 & 2 & 2 \\
\hline \multicolumn{4}{|l|}{ Intermediate goods firms } \\
\hline Tradable - bias toward capital $\left(\alpha_{T}\right)$ & 0.35 & 0.35 & 0.42 \\
\hline Nontradable - bias toward capital $\left(\alpha_{N}\right)$ & 0.35 & 0.3 & 0.3 \\
\hline \multicolumn{4}{|l|}{ Final consumption goods } \\
\hline Subst. btw. domestic and imported $\left(\mu_{T C}\right)$ & 2.5 & 2.5 & 2.5 \\
\hline Subst. Imported $\left(\mu_{M C}\right)$ & 2.5 & 2.5 & 2.5 \\
\hline Bias toward domestic tradables $\left(v_{T C}\right)$ & 0.0692 & 0.3872 & 0.3601 \\
\hline Subst. btw. tradable and nontradable $\left(\mu_{C}\right)$ & 0.5 & 0.5 & 0.5 \\
\hline Bias toward tradable $\left(v_{C}\right)$ & 0.45 & 0.475 & 0.7 \\
\hline \multicolumn{4}{|l|}{ Final investment goods } \\
\hline Subst. btw. domestic and imported $\left(\mu_{T I}\right)$ & 2.5 & 1.5 & 1.5 \\
\hline Subst. Imported $\left(\mu_{M I}\right)$ & 2.5 & 2.5 & 2.5 \\
\hline Bias toward domestic tradables $\left(v_{T I}\right)$ & 0.1735 & 0.2336 & 0.0024 \\
\hline Subst. btw. tradable and nontradable $\left(\mu_{I}\right)$ & 0.5 & 0.5 & 0.5 \\
\hline Bias toward tradable $\left(v_{I}\right)$ & 0.75 & 0.75 & 0.89 \\
\hline \multicolumn{4}{|l|}{ Final government consumption goods } \\
\hline Subst. btw. domestic and imported $\left(\mu_{T C G}\right)$ & 2.5 & 2.5 & 2.5 \\
\hline Subst. Imported $\left(\mu_{M C G}\right)$ & 2.5 & 2.5 & 2.5 \\
\hline Bias toward domestic tradables $\left(v_{T C G}\right)$ & 0.5168 & 0.2084 & 0.5247 \\
\hline Subst. btw. tradable and nontradable $\left(\mu_{C G}\right)$ & 0.5 & 0.5 & 0.5 \\
\hline Bias toward tradable $\left(v_{C G}\right)$ & 0.8 & 0.8 & 0.8 \\
\hline \multicolumn{4}{|l|}{ Final government investment goods } \\
\hline Subst. btw. domestic and imported $\left(\mu_{T I G}\right)$ & 2.5 & 2.5 & 2.5 \\
\hline Subst. Imported $\left(\mu_{M I G}\right)$ & 2.5 & 2.5 & 2.5 \\
\hline Bias toward domestic tradables $\left(v_{T I G}\right)$ & 0.3696 & 0.4252 & 0.3787 \\
\hline Subst. btw. tradable and nontradable $\left(\mu_{I G}\right)$ & 0.5 & 0.5 & 0.5 \\
\hline
\end{tabular}


Bias toward tradable $\left(v_{I G}\right)$

Final export goods

Subst. btw. domestic and imported $\left(\mu_{X}\right)$

Subst. Imported $\left(\mu_{M X}\right)$

1.5

1.5

1.5
2.5

1.5

Bias toward domestic tradables $\left(v_{X}\right)$

0.2212

2.5



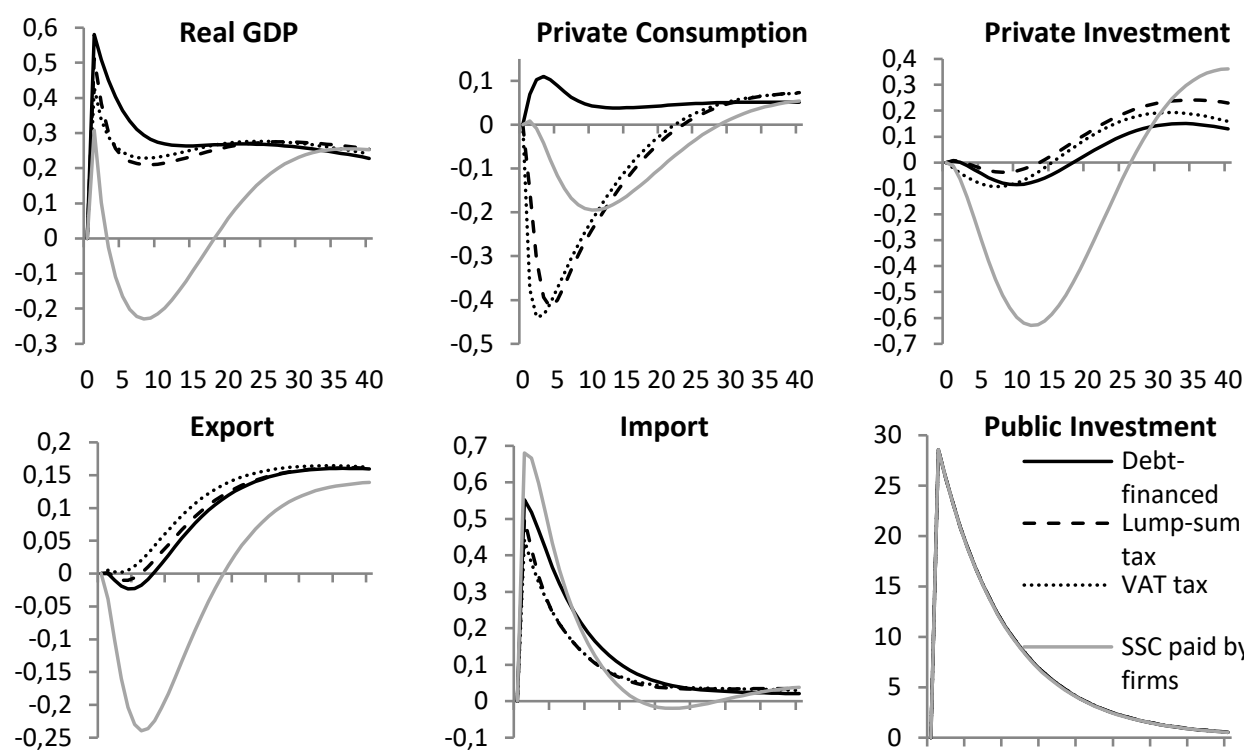

$0 \quad 510152025303540$

$0 \quad 510152025303540$
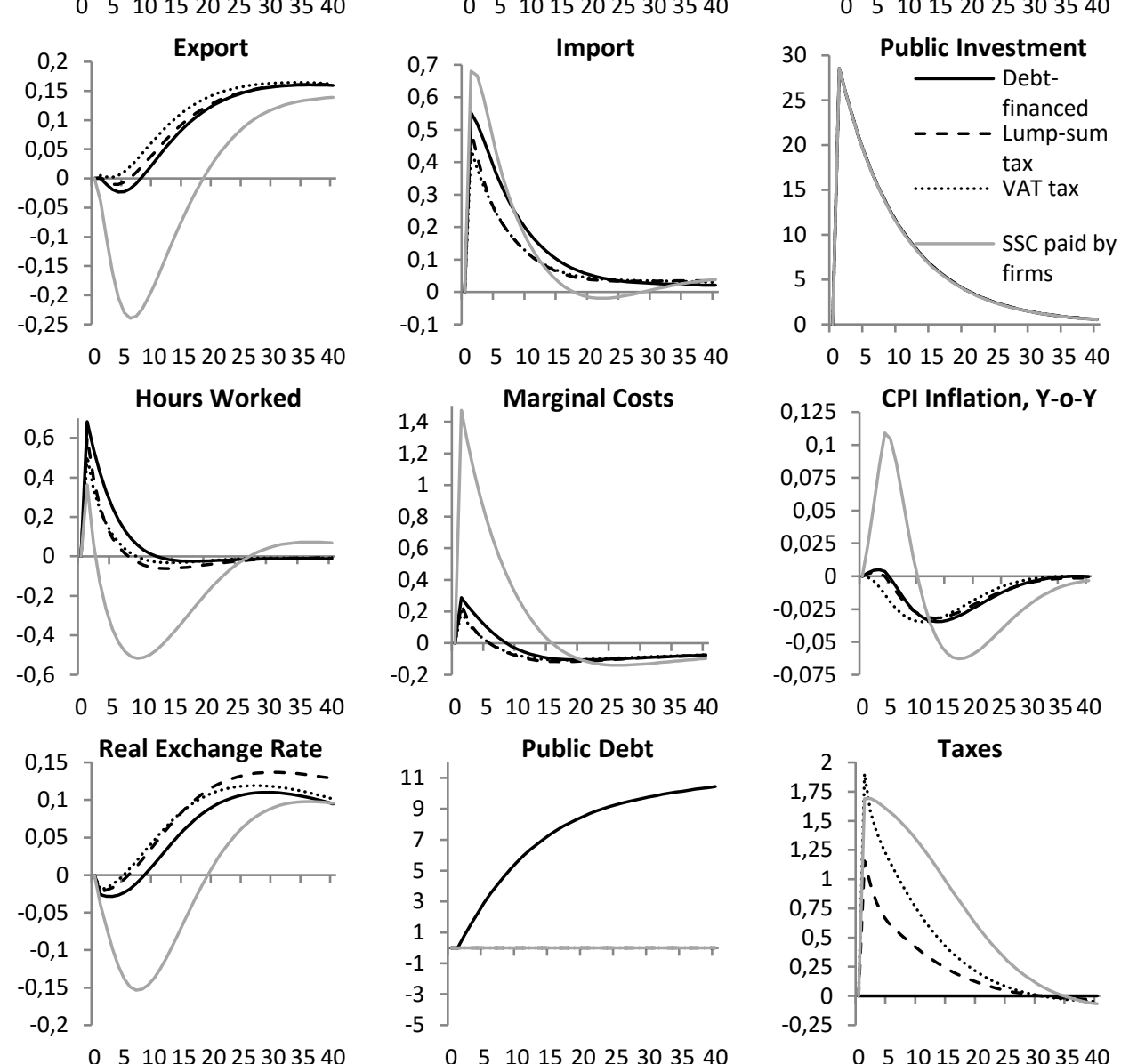

0510152025303540

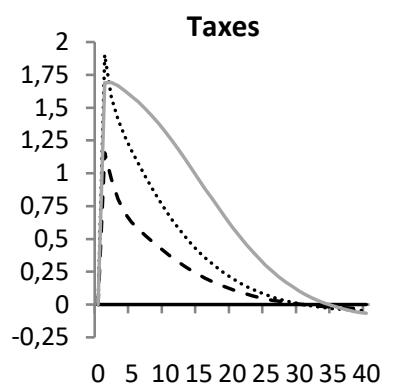

Fig. 2. Government investment shock - comparison of different types of financing (deviations from steady state in \%). 

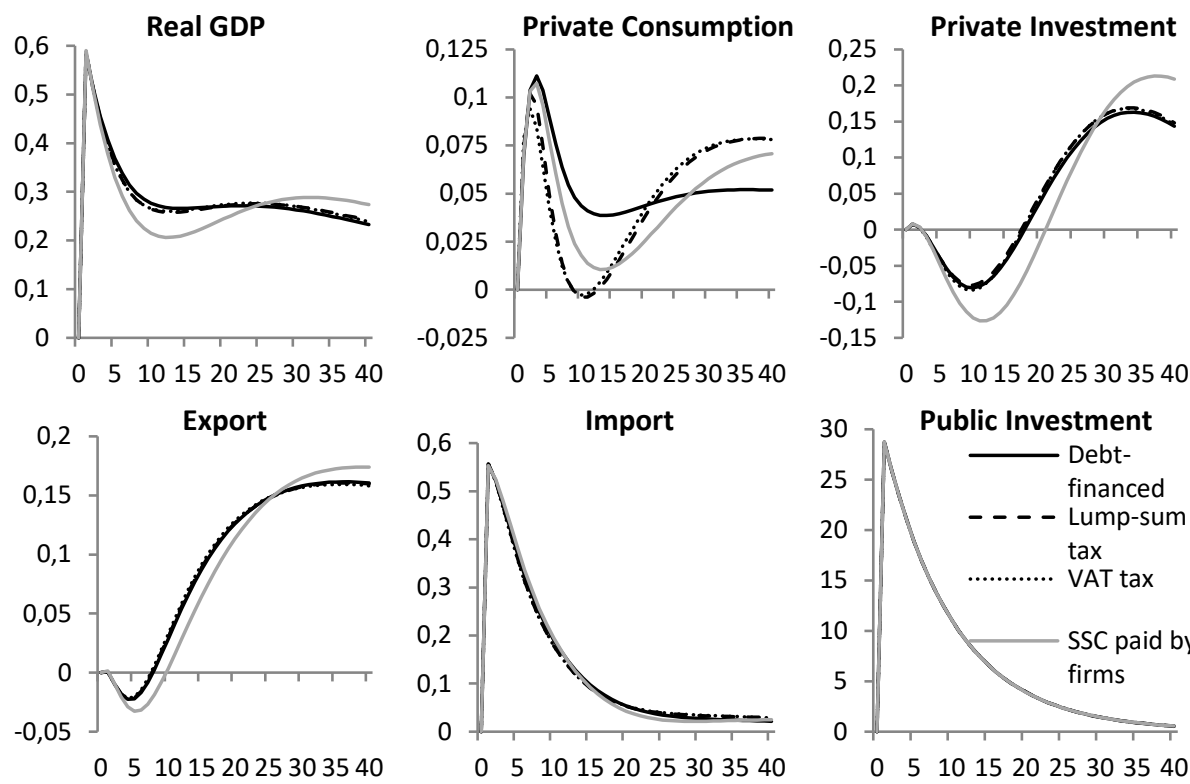

0510152025303540

$0 \quad 510152025303540$
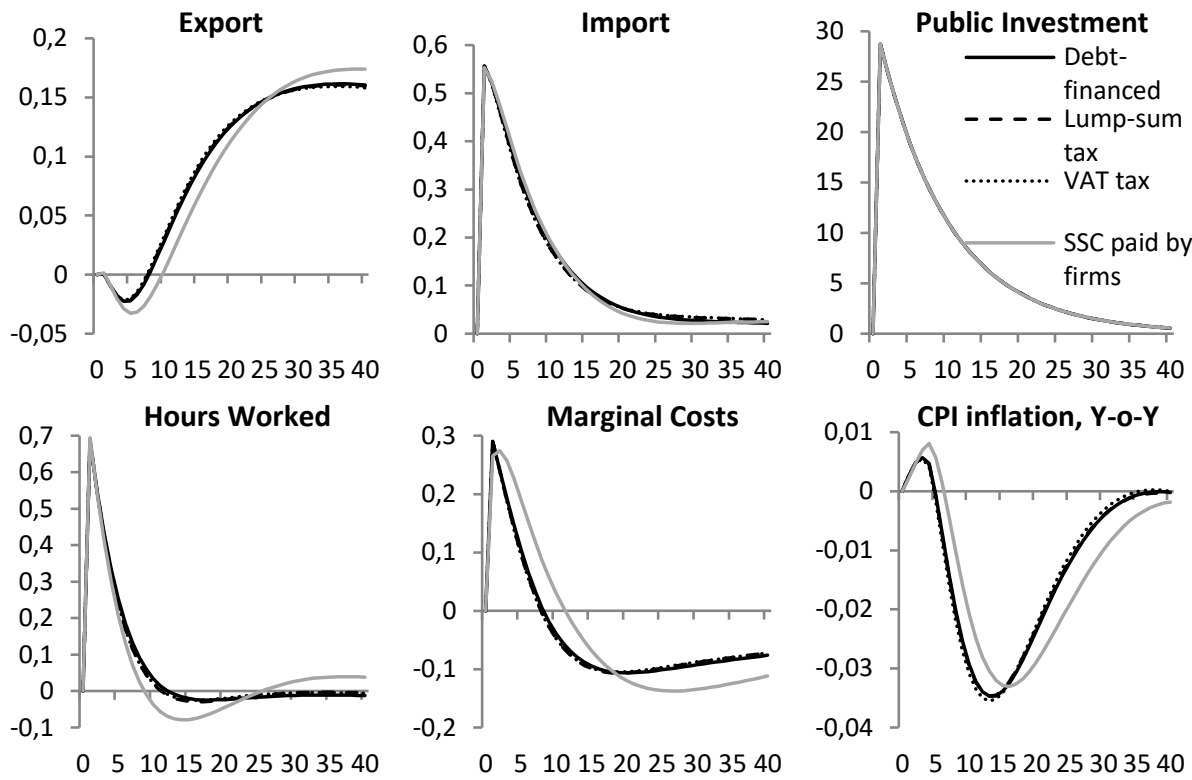

$0 \quad 510152025303540$
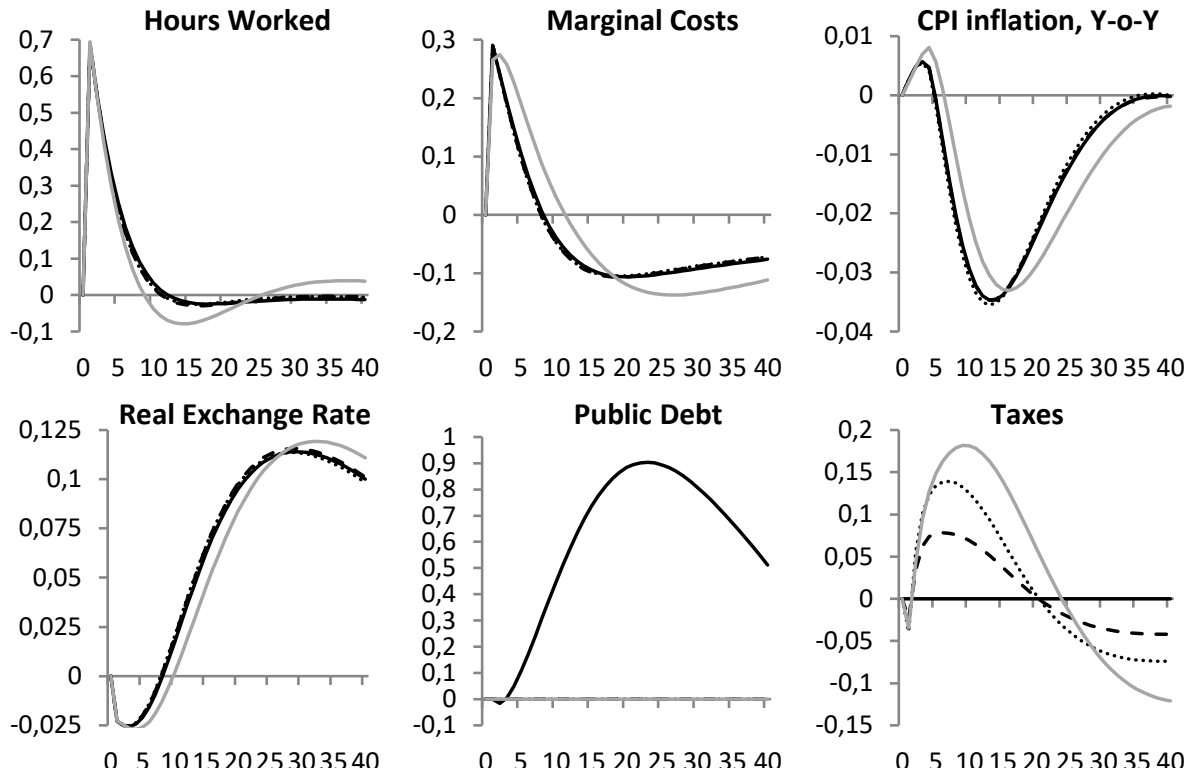

Fig. 3. EU funds shock - comparison of different types of financing (deviations from steady state in \%). 